J. Clin. Chem. Clin. Biochem.

Vol. 23, 1985, pp. 213-214

\title{
Specimen Collection Time for Enzyme Analysis in Urine
}

\author{
By F. Barragán, J. Fuentes, J. Orts and A. Castelao \\ Servicio de Bioquimica y Servicio de Nefrologia, Hospital de Bellvitge "Princeps d'Espanya", \\ Feixa Llarga S/N. L'Hospitalet de Llobregat (Barcelona) Spain
}

(Received August 17/December 17, 1984)

Summary: Catalytic activity of $\mathrm{N}$-acetyl- $\beta$ - $D$-glucosaminidase, alanine aminopeptidase, lactate dehydrogenase, isoenzyme 1 of lactate dihydrogenase, lysozyme, $\gamma$-glutamyl transferase and alkaline phosphatase in urine specimens collected between $6 \mathrm{a} . \mathrm{m}$. and $9 \mathrm{a} . \mathrm{m}$. were determined in 25 patients with acute renal failure. We found no statistical differences (Wilcoxon's $t$ test) between specimens collected at $6 \mathrm{a} . \mathrm{m}$. and 9 a. $\mathrm{m}$. We conclude that, in renal patients, the first morning specimen (overnight urine) may be used for enzyme analysis.

\section{Zeit der Probennahme für die Analyse von Enzymen im Harn}

Zusammenfassung: Bei 25 Patienten mit akutem Nierenversagen wurden die katalytischen Aktivitäten von $\mathrm{N}$-acetyl- $\beta$ - $D$-glucosaminidase, Alaninaminopeptidase, Lactatdehydrogenase, deren Isoenzym 1, Lysozym, $\gamma$ Glutamyltransferase und alkalischer Phosphatase in zwischen 6 und $9 \mathrm{Uhr}$ gesammelten Harnproben bestimmt. Wir fanden keine statischen Differenzen (Wilcoxon's t-Test) zwischen den um 6 und um $9 \mathrm{Uhr}$ gesammelten Proben. Wir schließen daraus, daß bei Nierenpatienten der erste Morgenurin (Nachturin) für Enzymanalysen benutzt werden kann.

\section{Introduction}

Rosalki \& Wilkinson began the study of urinary enzymes as possible renal damage markers in 1959 (1). These authors found high catalytic concentrations of lactate dehydrogenase in urines from subjects with all types of renal disease.

Later, the determination of some urinary enzymes as a diagnostic aid in renal diseases was proposed (2, 3). Excretion of enzymes in the urine shows great biological variation and is nearly always subject to circadian rhythm. It is recommended that urine be collected between 6 a.m. and 9 a.m., because this time coincides with the highest urinary excretion peak
$(4,5)$. Neither the 6 a.m. urine collection nor the 9 a.m. collection, however is representative when measuring toxic alterations of the kidney. On the other hand, collection of all urine voided between 6 a. m. and 9 a. m. is obviously less practicable than the collection of the first morning specimen (overnight urine).

In our laboratory we are studying the clinical usefulness of a number of enzymes in the urine of patients with acute renal failure. In these patients we have studied the difference in catalytic activity between specimens collected at $6 \mathrm{a}$. m. and specimens collected at 9 a.m. 


\section{Materials and Methods}

25 patients with acute renal failure, 15 men and 10 women between 30 and 60 years old, were studied.

The enzymes studied were: $N$-acetyl- $\beta$ - $D$-glucosaminidase (EC 3.2.1.30), determined according to the procedures described by Knoll et al. (6); alanine aminopeptidase (EC 3.4.11.2), determined according to Jung \& Scholz's colorimetric method (7); lactate dehydrogenase (EC 1.1.1.27), determined with the kit reference 124885 from Boehringer Mannheim, (Mannheim, F. R. of Germany); and isoenzyme 1 of lactate dehydrogenase, determined with the same reagents after immunoprecipitation of M-subunits with the kit 43145 Hoffmann La Roche (New Jersey, USA); lysozyme (EC 3.2.1.17), determined with the kit reference ORYY from Behringwerke (Marburg, F.R. of Germany); $\gamma$-glutamyl transferase (EC 2.3.2.2), assayed with the kit reference 158208 from Boehringer Mannheim; alkaline phosphatase (EC 3.1.3.1), determined with the kit reference OSOR 11 from Behringwerke. All determinations were performed at $37^{\circ} \mathrm{C}$. Alkaline phosphatase, lactate dehydrogenase, isoenzyme 1 of lactate dehydrogenase and $\gamma$-glutamyl transferase were assayed with the ABA-100 Bichromatic Analyser (Abbot Laboratories,South Pasadena, California, USA); Nacetyl- $\beta$ - $D$-glucosaminidase, alanine aminopeptidase and lysozyme were determined with the Shimadzu UV-240 spectrometer (Shimadzu Corporation, Japan).

Urine specimenis' were chromatographed with Sephadex G-25 fine (Pharmacia, Uppsala, Sweden) to eliminate interfering material (6).

The eluate was stored at $4^{\circ} \mathrm{C}$ and analysed not later than a week after voiding. The enzymes in the eluate are stable under these conditions $(6,8)$.
The statistical comparison was made with the non parametric Wilcoxon's $T$ test between the first collection at $6 \mathrm{a} . \mathrm{m}$. and the second one at 9 a. m. Catalytic activities were expressed in $\mu \mathrm{kat} /$ mol of creatinine, except for lysozyme, which was expressed in $\mathrm{mg} / \mathrm{mol}$ of creatinine.

\section{Results and Discussion}

The results obtained from each enzymes as well as the statistical comparison $(\alpha=0.05)$ are shown in table 1. Using the statistical test mentioned above, we found no significant differences between catalytic activity in urines collected at $6 \mathrm{a} . \mathrm{m}$. and $9 \mathrm{a} . \mathrm{m}$. in patients with acute renal failure. Taking into consideration that there are significant differences in healthy subjects (4), we suppose that in acute renal failure there is an alteration in the circadian rhythm of urinary enzyme excretion. On the basis of these results and bearing in mind the difficulty of specimen collection during a three hour period (from 6 a.m. to 9 a. m.), we consider that the first morning specimen (overnight urine) is suitable for the determination of excreted enzymes in subjects with acute renal failure and probably other renal alterations, i.e. enzymatic determinations can be made in the same urine that is used for routine urine analysis.

Tab. 1. Statistical comparison of enzymatic activities in urine between different collection times (6 a. m. and 9 a.m) from 25 patients (15 men and 10 women) with acute renal failure.

Enzyme activities were calculated in $\mu \mathrm{kat} / \mathrm{mol}$ of creatinine, excepting lysozyme which was expressed in $\mathrm{mg} / \mathrm{mol} \mathrm{of}$ creatinine.

$\overline{\mathrm{x}}=$ mean; $($ ) = range; NS = "not significant"

\begin{tabular}{|c|c|c|c|}
\hline Enzyme & $\begin{array}{l}\text { Urine at } \\
6 \text { a. m. }\end{array}$ & $\begin{array}{l}\text { Urine at } \\
9 \text { a.m. }\end{array}$ & $\begin{array}{l}\text { Wilcoxon's } \\
\text { T test }\end{array}$ \\
\hline Alanine aminopeptidase & $\begin{aligned} \bar{x}= & 398 \\
& (2-2613)\end{aligned}$ & $\begin{aligned} \dot{\bar{x}}= & 370 \\
& (2-2564)\end{aligned}$ & NS \\
\hline$N$-Acetyl- $\beta$ - $D$-glucosaminidase & $\begin{aligned} \bar{x}= & 368 \\
& (18-2032)\end{aligned}$ & $\begin{aligned} \overline{\mathbf{x}}= & 371 \\
& (1-1803)\end{aligned}$ & NS \\
\hline Lysozyme & $\begin{aligned} \overline{\mathrm{x}}= & 224 \\
& (0-1776)\end{aligned}$ & $\begin{aligned} \overline{\mathrm{x}}= & 195 \\
& (0-1916)\end{aligned}$ & NS \\
\hline Lactate dehydrogenase isoenzyme 1 & $\begin{aligned} \bar{x}= & 69 \\
& (0-407)\end{aligned}$ & $\begin{aligned} \bar{x}= & 119 \\
& (0-1017)\end{aligned}$ & NS \\
\hline$\gamma$-Glutamyltransferase & $\begin{aligned} \bar{x}= & 101 \\
& (0-1042)\end{aligned}$ & $\begin{aligned} \bar{x}= & 120 \\
& (0-1072)\end{aligned}$ & NS \\
\hline Alkaline phosphatase & $\begin{aligned} \bar{x}= & 155 \\
& (11-521)\end{aligned}$ & $\begin{aligned} \bar{x}= & 159 \\
& (7-589)\end{aligned}$ & NS \\
\hline
\end{tabular}

\section{References}

1. Rosalki, S. B. \& Wilkinson, J. (1959) Lancet II, 327-328.

2. Raab, W. (1972) Clin. Chem. 18, 5-20.

3. Vanderlinde, R. E. (1981) Ann. Clin. Lab. Sci. 11, 189-201.

4. Maruhn, D., Strozyk, K., Gielow, L. \& Bock, K. D. (1977) Clin. Chim. Acta 75, 427-433.

5. Lakatua, D. J., Blomquist, CH., Haus, E., Sackett-Lundeen, L., Berg, H. \& Swoyer, J. (1982) Am. J. Clin. Pathol. 78, $69-77$.
6. Knoll, E., Wisser, H. \& Rautenstrauch, H. (1980) J. Clin. Chem. Clin. Biochem. 18, 53-58.

7. Jung, K. \& Scholz, D. (1980) Clin. Chem. 26, 1251-1254.

8. Diener, U., Knoll, E., Langer, B., Rautenstrauch, H., Ratge, D. \& Wisser, H. (1981). Clin. Chim. Acta 112, 149-1.57.

\section{F. Barragán}

Servicio de Bioquimica

Hospital de Bellvitge "Princeps d'Espanya"

Feixa Llarga $S / N$

L'Hospitalet de Llobregat (Barcelona)

Spain

J. Clin. Chem. Clin. Biochem. / Vol. 23, 1985 / No. 4 